\title{
Penerapan Model Student Facilitator and Explaining (SFE) dengan Media Poster untuk Meningkatkan Kemampuan Representasi Matematis Siswa
}

\author{
Sonia Andam Sari ${ }^{1}$, Eline Yanty Putri Nasution ${ }^{2 *}$, Laswadi $^{3}$ \\ 1, 2, 3 Jurusan Tadris Matematika, Fakultas Tarbiyah dan Ilmu Keguruan (FTIK), \\ Institut Agama Islam Negeri (IAIN) Kerinci \\ 1..sonia83@yahoo.com \\ 2elineyantyputrinasution@iainkerinci.ac.id \\ 3laswadi@iainkerinci.ac.id
}

\begin{abstract}
This study used quantitative approach with experiment method. The research design was posttestonly control group. The purpose of this study was to investigate the effect of cooperative learning model type Student Facilitator and Eksplaining (SFE) with poster media through students, mathematical representation ability. The population was all of seventh grade students in SMPN 7 Sungai Penuh. Two sample were choosen withdraw. Conventional method was implemented in control group, while cooperative learning model type Student Facilitator and Eksplaining (SFE) with poster media was implemented in experiment group. The instrument in this study was students' mathematical representation ability test that the test items was analyzed first. The instrument was given in the end of learning process in both groups. The result of the data analysis was obtained that: (1) the average of students' mathematical representation ability test in control group was 66,67 while in experiment group was 73,43; (2) the students' mathematical representation ability who study under cooperative learning model type Student Facilitator and Eksplaining (SFE) with poster media was higher than who study under conventional method; (3) there was an effect of cooperative learning model type Student Facilitator and Eksplaining (SFE) with poster media through the students' mathematical representation ability.
\end{abstract}

Keywords: representation; student facilitator and eksplaining; SFE; poster; cooperative learning model.

\begin{abstract}
Abstrak
Penelitian ini menggunakan pendekatan kuantitatif dengan metode eksperimen. Desain penelitian ini adalah posttest-only control group. Tujuan penelitian ini adalah untuk mengetahui apakah terdapat pengaruh model pembelajaran kooperatif tipe Student Facilitator and Eksplaining (SFE) dengan media poster terhadap kemampuan representasi matematis siswa. Populasi dalam penelitian ini adalah seluruh siswa kelas VII SMPN 7 Sungai Penuh. Dua sampel dipilih dengan cara pengundian. Pembelajaran dengan metode konvensional dilaksanakan pada kelas kontrol, sedangkan model pembelajaran koopertaif tipe Student Facilitator and Eksplaining (SFE) dengan media poster dilaksanakan pada kelas eksperimen. Instrumen pada penelitian ini adalah tes kemampuan representasi matematis siswa yang terlebih dahulu dilakukan analisis butir soal tes. Instrumen diberikan pada akhir proses pembelajaran di kedua kelas. Hasil analisis data diperoleh bahwa: (1) rata-rata tes kemampuan representasi matematis siswa pada kelas kontrol adalah 66,67 sedangkan pada kelas eksperimen adalah 73,43; (2) kemampuan representasi matematis siswa yang belajar dengan model pembelajaran kooperatif tipe Student Facilitator and Eksplaining (SFE) dengan media poster lebih tinggi daripada kemampuan representasi matematis siswa yang belajar dengan metode konvensional; dan (3) terdapat pengaruh model pembelajaran kooperatif tipe Student Facilitator and Eksplaining (SFE) dengan media poster terhadap kemampuan representasi matematis siswa.
\end{abstract}

Kata Kunci: representasi; student facilitator and eksplaining; SFE; poster; model pembelajaran kooperatif.

\footnotetext{
*Correspondence:

Email: elineyantyputrinasution@iainkerinci.ac.id
} 


\section{PENDAHULUAN}

Pendidikan adalah suatu proses pembentukan kepribadian manusia yang memungkinkan pertumbuhan dan perkembangan semua potensi dan sumber daya yang dimiliki oleh seseorang. Proses pendidikan yang berlangsung di sekolah merupakan suatu kegiatan belajar mengajar, yaitu aktivitas yang melibatkan guru dan siswa secara bersama-sama untuk mencapai tujuan pembelajaran tertentu. Pendidikan sangat pentinga tanpa adanya pendidikan manusia akan sulit berkembang dan bahkan akan terbelakang (Mulyasa, E., 2004). Melalui pendidikan, manusia akan memperoleh pengetahuan, keterampilan, serta perilaku yang lebih baik dalam proses belajar sehingga menimbulkan suatu perubahan perilaku dimana siswa yang semulanya belum tahu menjadi tahu.

Tujuan pendidikan di dalam Undang-Undang No. 20 tahun 2003 tentang Sistem Pendidikan Nasional adalah untuk mengembangkan potensi siswa agar memiliki kekuatan spiritual keagamaan, pengendalian diri, kepribadian, kecerdasan, akhlak mulia, serta keterampilan yang diperlukan bagi dirinya, masyarakat bangsa dan negara. Pemerintah telah berusaha untuk meningkatkan kualitas pendidikan dengan berbagai cara, seperti merubah kurikulum mata pelajaran dari tahun ke tahun sesuai dengan kebutuhan sekarang dan masa yang akan datang serta meningkatkan kualitas pendidikan guru ke Srata Satu (S-1) atau lebih meningkatkan kualitas dan kuantitas pendidikan guru. Namun jika diperhatikan pada masa sekarang, kualitas dan hasil pendidikan atau hasil belajar siswa masih terlihat rendah terutama pada mata pelajaran matematika.

Matematika adalah salah satu mata pelajaran yang dipelajari di sekolah dan sangat diperlukan dalam kehidupan sehari-hari maupun dalam perkembangan ilmu dan teknologi (IPTEK). Matematika dapat membentuk pola pikir yang sistematis, logis, kritis dengan penuh kecermatan (Hasratuddin, 2013). Oleh sebab itu, seorang guru perlu mengajar matematika dengan menggunakan strategi pembelajaran invotif diikuti penggunaan media pembelajaran agar dapat memperjelas materi yang diajarkan selama proses pembelajaran. Matematika dianggap sulit oleh sebagian besar siswa pada semua tingkatan pendidikan, mulai dari sekolah dasar sampai sekolah lanjutan. Hal ini dibuktikan dari hasil nilai ujian matematika siswa pada setiap tahun selalu menduduki nilai terendah di antara mata pelajaran yang lainnya. Sementara itu, matematika merupakan mata pelajaran yang berperan penting dalam mendukung kemajuan ilmu pengetahuan dan teknologi (Saifuddin, A., Nasikh, N., \& Utomo, S. H., 2015).

Rendahnya hasil belajar siswa disebabkan karena siswa sering merasa kesulitan dalam merepresentasikan objek-objek dan simbol-simbol matematis yang sering dijumpai pada permasalahan matematika. Materi-materi yang berkaitan dengan matematika membutuhkan daya pikir tingkat tinggi dalam memahami hubungan dan sifat-sifat matematis dalam rangka menyelesaikan suatu 
permasalahan matematika (Nasution, E.Y.P., 2017). Hal tersebut juga didukung oleh hasil observasi awal penulis yang menemukan bahwa kebanyakan siswa merasa kesulitan dalam mengartikan atau merepresentasikan bahasa matematika khususnya permasalahan dalam bentuk soal cerita. Siswa sering salah mengartikan dan menginterpretasikan kalimat matematika terutama yang berkaitan dengan masalah dalam kehidupan sehari-hari. Untuk itu, perlu dikembangkan kemampuan representasi matematis pada siswa.

Representasi adalah bentuk interpretasi pemikiran siswa terhadap suatu masalah, yang digunakan sebagai alat bantu untuk menemukan solusi dari masalah tersebut. Bentuk interpretasi siswa dapat berupa kata-kata atau verbal, tulisan, gambar, tabel, grafik, benda konkrit, simbol matematika dan lain-lain (Sabirin, M., 2014). Representasi matematis merupakan penggambaran, penterjemahan, pengungkapan, penunjukan kembali, pelambangan atau bahkan pemodelan dari ide, gagasan, konsep matematik, dan hubungan di antaranya yang termuat dalam suatu konfigurasi, konstruksi, atau situasi masalah tertentu yang ditampilkan siswa dalam bentuk beragam sebagai upaya memperoleh kejelasan makna, menunjukkan pemahamannya, atau mencari solusi dari masalah yang dihadapinya (Rangkuti, A.N., 2014).

Beberapa komponen seperti guru, siswa, materi pengajaran, dan evaluasi belajar mengajar sangat berpengaruh untuk mencapai tujuan pembelajaran. Guru sebagai faktor utama dalam kegiatan pendidikan berkewajiban untuk mengorganisasikan proses pembelajaran sedemikian sehingga materi pelajaran dapat dipahami siswa. Guru hendaknya menggunakan model pembelajaran yang melibatkan keaktifan siswa dalam proses pembelajaran sehingga siswa merasa dihargai dan dapat mengembangkan potensi dirinya melalui adanya hubungan timbal balik antara guru dan siswa. Komunikasi dua arah antara guru dan siswa diyakini mampu mencapai hasil belajar yang lebih baik. Guru juga harus mampu menyesuaikan strategi pembelajaran dengan materi yang diajarkan agar dapat memberikan efek positif terhadap peningkatan hasil belajar siswa (Zahara, R., 2017).

Proses belajar mengajar sebaiknya lebih banyak melibatkan aktivitas siswa, dimana siswa tidak hanya mendengar, memahami, dan pemperhatikan guru, tetapi siswa juga hendaknya dituntut untuk aktif dalam proses pembelajaran dan berani untuk mengungkapkan pendapat. Selain itu, proses pembelajaran juga hendaknya memungkinkan para siswa untuk saling bertanya dan menjelaskan selayaknya seorang guru di antara mereka.

Untuk mencapai suatu pendidikan yang berkualitas dibutuhkan proses pembelajaran atau strategi dalam belajar mengajar yang sangat berpengaruh dalam pencapaian presentasi belajar siswa. Salah satu strategi belajar mengajar yang dapat meningkatkan aktivitas dan kemampuan siswa adalah melalui penggunaan model pembelajaran kooperatif. Beberapa ahli setuju dengan model pembelajaran 
kooperatif tipe Student Facilitator and Explaining (SFE) yang tidak hanya unggul dalam membantu siswa untuk memahami konsep-konsep matematika, tetapi juga dapat menumbuhkan kemampuan kerjasama dan bertanggung jawab terhadap sesama teman kelompok dalam rangka mencapai tujuan kelompok (Zahara, R., 2017).

Model pembelajaran Student Facilitator and Explaining (SFE) adalah model pembelajaran yang bertujuan mendorong siswa dapat aktif dalam proses pembelajaran yaitu dengan menyampaikan ide dan gagasannya kepada siswa lainnya yang berhubungan dengan materi ajar. Aktivitas siswa dalam menyampaikan ide dan gagasannya diyakini dapat melatih kemmapuan siswa dalam menginterpretasikan materi dan persoalan matematika yang sedang dibahas. Model pembelajaran Student Facilitator and Explaining (SFE) adalah model pembelajaran dimana siswa atau peserta didik mempresentasikan ide atau pendapatnya kepada rekan siswa lainnya (Saifuddin, A., Nasikh, N., \& Utomo, S. H., 2015). Kegiatan presentasi ini tentu saja dapat memicu kemampuan representasi matematis siswa. Pada proses penerapan model pembelajaran Student Facilitator and Explaining (SFE), guru juga berperan penting dalam menyajikan materi ajar secara garis besar kepada siswa agar siswa paham dan bersedia mempresentasikan materi ajar kembali di depan kelas. Gagasan dasar dari strategi pembelajaran ini adalah bagaimana guru mampu menyajikan atau mendemonstrasikan materi di depan siswa lalu memberikan siswa kesempatan untuk menjelaskan kepada teman-temannya (Huda, M., 2014). Sajian dan demonstrasi guru dapat menjadi contoh bagi siswa terkait cara menginterpretasikan suatu permasalahan matematis. Pada akhirnya, penerapan model Student Facilitator and Explaining (SFE) dalam proses pembelajaran diharapkan dapat meningkatkan aktivitas siswa dalam kegiatan belajar mengajar, serta meningkatkan pemahaman siswa terhadap materi ajar sehingga selanjutnaya akan meningkatkan prestasi belajar siswa (Saifuddin, A., Nasikh, N., \& Utomo, S. H., 2015).

Media pembelajaran poster merupakan salah satu media yang tediri dari lambang atau kata simbol yang sangat sederhana, poster juga sebagai kombinasi visual dari rancangan yang kuat, dengan warna dan pesan dengan maksud untuk menangkap perhatian siswa (Maiyena, S., 2013). Media poster ini tentu saja dapat mendukung daya representasi matematis siswa. Media poster dapat memberi nuansa belajar yang menarik dan efektif selama belajar matematika. Penggunaan poster sebagai media diharapkan mampu membuat siswa menjadi lebih mudah dalam memahami materi pembelajaran matematika. Materi yang disajikan dengan media poster mampu memotivasi siswa dalam belajar matematika melalui demonstrasi sehingga mampu meningkatkan aktivitas belajar siswa (Maiyena, S., 2013). 
Penggunaan media poster dalam model pembelajaran kooperatif tipe Student Facilitator and Explaining (SFE) diharapkan mampu meminimalisir kelemahan model pembelajaran ini, yaitu: (1) siswa yang pemalu tidak mau mendemontrasikan apa yang diperintahkan oleh guru kepadanya atau banyak siswa yang kurang aktif; (2) tidak semua siswa memiliki kesempatan yang sama untuk melakukannya atau menjelaskan kembali kepada teman-temanya karena keterbatasan waktu pelajaran; (3) adanya pendapat yang sama sehingga hanya sebagian saja yang terampil; dan (4) tidak mudah bagi siswa untuk membuat poster atau menerangkan materi ajar secara ringkas (Fauzi, M. N., \& Jati, N. H. D., 2016)

Langkah-langkah pembelajaran yang digunakan dengan model pembelajaran kooperatif tipe Student Facilitator and Explaining (SFE) adalah sebagai berikut: (1) guru mencapaikan kompetensi yang inggi dicapai; (2) guru mendemontrasikana atau menyajikan garis-garis besar materi pelajaran; (3) setiap kelompok ditunjukkan satu orang yang bertugas sebagai fasilitator dan bertanggung jawab sebagai penjelas materi pelajaran kepada kelompoknya; (4) guru membagikan LKS dan memeberikan waktu kepada masing-masing kelompok untuk mediskusikan serta memanfaatkan media sebagi media pembelajaran; (5) guru memberikan kesempatan kepada siswa untuk menjelaskan kepada siswa yang lainnya tentang materi pelajaran yang dibahas melalui media pembelajaran yang telah dibuat siswa dalam kelompok; (6) guru menyimpulkan ide atau pendapat dari siswa; (7) guru menerangkan materi yang belum dipahami siswa secara singkat dan jelas; dan (8) penutup (Huda, M., 2014).

\section{METODE PENELITIAN}

Penelitian ini menggunakan pendekatan kuantitatif dengan metode eksperimen. Penelitian eksperimen adalah suatu penelitian yang berusaha mencari pengaruh variabel tertentu terhadap variabel yang lain dalam kondisi yang terkontrol secara ketat. Kelas eksperimen adalah kelas yang diajarkan dengan menggunakan model pembelajaran Student Facilitator and Explaining (SFE) dengan menggunakan media Poster. Kelas kontrol dalam penelitian ini adalah kelas yang tidak diajarkan dengan menggunakan model pembelajaran Student Facilitator and Explaining (SFE) dengan menggunakan media poster. Pada akhir proses pembelajaran kedua kelas itu diberikan tes akhir.

Adapun desain penelitian yang diterapkan pada penelitian ini menggunakan posttest-only control group design yang dipaparkan pada Tabel.1. Sedangkan populasi penelitian ini adalah siswa kelas VII SMP Negeri 7 Sungai Penuh yang terdaftar pada Tahun Pelajaran 2019/2020. Data jumlah siswa sebagai populasi penelitian ini dapat dilihat pada Tabel.2. 
Tabel 1. Rancangan Penelitian Posttest-Only Control Group Design

\begin{tabular}{ccc}
\hline Kelas & Treatment & Tes Akhir \\
\hline Eksperimen & $\mathrm{X}$ & $\mathrm{T}$ \\
\hline Kontrol & - & $\mathrm{T}$ \\
\hline
\end{tabular}

Keterangan :

$\mathrm{X} \quad$ : diterapkan dengan Model Pembelajaran Student Facilitator and Explaining (SFE) dengan Menggunakan Media Poster

T : Posttest untuk kelas eksperimen dan kelas kontrol untuk melihat perbandingan antara keduanya.

Tabel 2. Jumlah Siswa Kelas VII SMP Negeri 7 Sungai Penuh 2019/2020

\begin{tabular}{ccc}
\hline NO & KELAS & JUMLAH SISWA \\
\hline 1. & VII $_{\mathrm{A}}$ & 18 \\
\hline 2. & $\mathrm{VII}_{\mathrm{B}}$ & 19 \\
\hline 3. & $\mathrm{VII}_{\mathrm{C}}$ & 17 \\
\hline & JUMLAH & 54 \\
\hline
\end{tabular}

Penelitian ini membutuhkan 2 kelas sebagai sampel yaitu sebagai kelas eksperimen dan kelas kontrol. Prosedur yang dilakukan agar sampel yang diambil refresentatif adalah menguji apakah sampel berasal dari populasi yang sama dan mempunyai nilai rata-rata yang sama. Sehingga sampel yang refresentatif ini dapat mewakili populasi. Setelah diadakan pengujian, peneliti mengambil kelas sampel dengan berdasar kepada hasil pengujian tehadap semua populasi.

Langkah pertama dalam menentukan sampel adalah mengumpulkan nilai ulangan matematika siswa kelas VII SMP Negeri 7 Sungai Penuh Tahun Pelajaran 2019/2020. Langkah berikutnya adalah melakukan uji normalitas. Hal ini dilakukan untuk mengetahui kenormalan data populasi dengan menggunakan uji liliefors. Hasil perhitungan uji normalitas populasi dipaparkan pada tabel berikut:

Tabel 3. Hasil Perhitungan Uji Normalitas Populasi

\begin{tabular}{ccccc}
\hline Kelas & $\mathbf{N}$ & $\boldsymbol{L}_{\text {hitung }}$ & $\boldsymbol{L}_{\text {tabel }}$ & Distribusi \\
\hline $\mathrm{VII}_{\mathrm{A}}$ & 18 & 0,1744 & 0,200 & Normal \\
\hline $\mathrm{VII}_{\mathrm{B}}$ & 19 & 0,162 & 0,195 & Normal \\
\hline $\mathrm{VII}_{\mathrm{C}}$ & 17 & 0,1973 & 0,206 & Normal \\
\hline
\end{tabular}

$\mathrm{H}_{0} \quad$ : Data berdistribusi normal

$\mathrm{H}_{1} \quad$ : Data tidak berdistribusi normal

Dari tabel di atas dihasolkan bahwa data populas terdistribusi normal. Langkah berikutnya adalah melakukan uji homogenitas varians populasi. Adapun hasil uji homogenitas varians populasi dipaparkan pada tabel berikut: 
Tabel 4. Harga Yang Diperlukan Untuk Melakukan Uji Homogenitas Populasi (Uji Barlett)

\begin{tabular}{|c|c|c|c|c|c|c|c|}
\hline Kelas & $\mathbf{n}$ & $\mathrm{dk}=\mathrm{n}-1$ & 1/dk & $\mathbf{S i}^{2}$ & $\mathrm{dkSi}^{2}$ & $\log \mathrm{Si}^{2}$ & $(\mathrm{dk}) \operatorname{logSi^{2}}$ \\
\hline $\mathrm{VII}_{\mathrm{A}}$ & 18 & 17 & 0,0588 & 129,01 & 2193,17 & 2,1106 & 35,8802 \\
\hline $\mathrm{VII}_{\mathrm{B}}$ & 19 & 18 & 0,0556 & 78,11 & 1405,98 & 1,8927 & 34,0686 \\
\hline $\mathrm{VII}_{\mathrm{C}}$ & 17 & 16 & 0,0625 & 93,48 & 1495,68 & 1,9707 & 31,5312 \\
\hline$\sum$ & 54 & 51 & 0,1769 & 30,06 & 5094,83 & 5,9740 & 101,4800 \\
\hline
\end{tabular}

Setelah dilakukannya langkah-langkah Uji Barlett Kemudian harga dibandingkan dengan $\chi_{(1-\alpha . k-1)}^{2}$. Kriteria pengujian tolak $\mathrm{H}_{0}$ jika $: \chi_{\text {hitung }}^{2} \geq$ $\chi_{(1-\propto, k-1)}^{2}$, dan terima $\mathrm{H}_{0}$ jika: $\chi_{\text {hitung }}^{2}<\chi_{(1-\alpha, k-1)}^{2}$, dimana didapat dari daftar distribusi chi-kuadrat dengan peluang $(1-\alpha)$ dan $\mathrm{dk}=(\mathrm{k}-1)$. Dari hasil uji homogenitas maka di dapat nilai $\chi_{\text {tabel }}^{2}$ dengan menetapkan $\alpha=0,05$ dan banyak sampel $\mathrm{n}=\mathrm{k}-1=3-1=2$ adalah $\chi_{(1-\alpha)(\mathrm{k}-1)}^{2}=\chi_{(0,95)(2)}^{2}=5,591$ maka $\chi_{\text {hitung }}^{2}=$ 1,1386 dan $\chi_{\text {tabel }}^{2}=5,591$, artinya $\chi_{\text {hitung }}^{2}<\chi_{\text {tabel }}^{2}$ sehingga dapat disimpulkan bahwa ketiga kelas populasi mempunyai variansi homogen pada tingkat kepercayaan 95\%. maka diperoleh populasi homogen artinya ketiga kelas mempunyai varians data yang homogen dan $\mathrm{H}_{0}$ diterima. Populasi yang mempunyai variansi homogen.

Data populasi terdistribusi normal dan memiliki varians yang homogen. Langkah berikutnya adalah melakukan uji kesamaan rata-rata populasi (Analisis Varians Satu Arah) bertujuan untuk melihat apakah terdapat perbedaan nilai ratarata populasi. Perhitungan uji kesamaan rata-rata populasi dipaparkan pada tabel berikut:

Tabel 5. Uji Kesamaan Rata-rata (Anava Satu Arah)

\begin{tabular}{cccc}
\hline Responden & $\mathbf{N}$ & $\mathbf{J i}$ & $\sum \mathbf{Y}^{2}$ \\
\hline VII $_{\mathrm{A}}$ & 18 & 1055 & 64925 \\
\hline VII $_{\mathrm{B}}$ & 19 & 1040 & 59100 \\
\hline $\mathrm{VII}_{\mathrm{C}}$ & 17 & 980 & 53050 \\
\hline Jumlah & $\mathbf{5 4}$ & $\mathbf{3 0 7 5}$ & $\mathbf{1 7 7 0 7 5}$ \\
\hline $\mathrm{H}_{0} \quad: \mu_{1}=\mu_{2}=\mu_{3}$ & \\
$\mathrm{H}_{1} \quad:$ Paling sedikit satu tanda sama dengan tidak berlaku
\end{tabular}

Setelah dilakukannya langkah-langkah teknik analisis varians satu arah jika $F_{\text {hitung }} \geq F_{(1-\alpha)\left(v_{1}, v_{2}\right)}$ diterima untuk taraf nyata $\alpha=0,05$ maka $\mathrm{H}_{0}$ ditolak, dalam hal ini $\mathrm{H}_{1}$ di terima. Dengan $\mathrm{dk}$ pembilang $\mathrm{V}_{1}=(\mathrm{k}-1)=3-1=2 \mathrm{dan} \mathrm{dk}$ penyebut $\mathrm{V}_{2}=\sum(\mathrm{n}-1)=51$ pada tingkat kepercayaan $95 \%$ (jadi $\alpha=0,05$ ) didapat $F_{(0,95)(2,51)}=1,91$ yang diperoleh dari daftar distribusi F. Berarti $F_{\text {hitung }=1,139}$ dan $F_{\text {tabel }}$ 3,178 maka $F_{\text {hitung }}<F_{\text {tabel }}$ sehingga dapat disimpulkan tidak terdapat perbedaan rata-rata nilai ulangan siswa kelas VII SMP Negeri 7 Sungai 
Penuh Tahun Pelajaran 2019/2020 dari tiga kelas populasi pada tingkat keprcayaan $95 \%$.

Setelah melakukan uji normalitas, uji homogenitas dan uji kesamaan ratarata dengan menggunakan teknik Anava satu arah, maka yang dilakukan selanjutnya adalah menentukan kelas sampel untuk mewakili populasi. Dalam hal ini, peneliti mengunakan teknik random sampling. Random sampling adalah suatu cara pengambilan sampel dimana dalam populasinya diberi kesempatan sama untuk dipilih menjadi kelas sampel. Teknik yang digunakan dalam menentukan kelas sampel adalah dengan cara undian. Dengan membuat gulungan kertas, yang masing-masing gulungan kertas tersebut terdapat satu kelas. Dari hasil unduan diperoleh kelas VII B sebagai kelas eksperimen dan kelas VII A sebagai kelas kontrol.

Variabel bebas pada penelitian ini adalah model pembelajaran Student Facilitator and Explaining (SFE) dengan Menggunakan Media Poster. Variabel terikat pada penelitian ini adalah Kemampuan Representasi Matematis. Pembelajaran akan dilaksanakan pada kedua kelas sampel. Perlakuan yang akan diberikan akan berbeda antara kelas eksperimen dan kelas kontrol. Pada kelas eksperimen diberikan pembelajaran dengan menggunakan model pembelajaran Student Facilitator and Explaining (SFE) dengan Menggunakan Media Poster sedangkan pada kelas kontrol diberikan pembelajaran yang konvensional.

Model Student Facilitator and Explaining (SFE) dengan Menggunakan Media Poster bukan hanya meningkatkan penguasaan matematika, tapi juga berbagai kemampuan belajar pada siswa, mulai dari konsentrasi dan ketangkasan kerja, semangat kebiasaan belajar mandiri, kebiasaan belajar setiap hari. Bila ia bisa menyelesaikan soal latihan matematika dari sekolah dengan cepat, maka ia bisa menggunakan sisa waktu untuk mempelajari ilmu lain. Alhasil, pelajaran lain pun pasti akan meningkat.

Pada tahap akhir penelitian, pada kelas eksperimen dan kelas kontrol diberikan tes untuk melihat kemampuan representasi matematis siswa pada kedua kelas tersebut. Tes yang diujikan berdasarkan materi yang diberikan selama penelitian berlangsung.

Instrumen yang digunakan pada penelitian ini adalah tes kemampuan representasi matematis yang didukung dengan observasi dan wawancara. Tes yang digunakan dalam tes ini adalah tes tertulis dalam bentuk essay. Soal tes disusun sesuai dengan kisi-kisi tes. Penyusunan tes dibuat berdasarkan tujuan pembelajaran khusus yang berkaitan dengan pokok bahasan. Sebelum diberikan kepada siswa kelas sampel, terlebih dahulu diuji cobakan ke kelas lain, uji coba ini dilakukan untuk menentukan reabilitas, tingkat kesukaran dan daya pembeda soal, sehingga tes yang diberikan tersebut mempunyai kualitas yang baik. 
Analisis data digunakan untuk menguji kebenaran hipotesis dan menjawab pokok masalah yang telah diajukan dalam penelitian ini. Dalam menguji hipotesis penguji membandingkan nilai rata-rata kelas eksperimen yang proses pembelajarannya menggunakan model pembelajaran Student Facilitator and Explaining ( $S F E$ ) dengan menggunakan media poster dan nilai rata-rata kelas kontrol dengan proses pembelajarannya menggunakan metode konvensional. Untuk melihat peningkatan kemampuan pemecahan masalah belajar secara statistik dilakukan uji t sebab data terdistribusi normal dan memiliki varians yang homogen.

\section{HASIL DAN PEMBAHASAN}

Penelitian ini dilakkukan untuk menjawab pertanyaan penelitian "Apakah terdapat pengaruh model pembelajaran kooperatif tipe Student Facilitator and Explaining (SFE) dengan menggunakan media poster terhadap kemampuan representasi matematis siswa". Data hasil belajar pada penelitian ini diperoleh dari tes kemampuan representasi matematis kedua kelas sampel. Tes kemampuan representasi matematis terdiri dari 4 butir soal essay diikuti oleh kedua kelas sampel yang terdiri dari 19 orang kelas eksperimen dan 18 orang siswa untuk kelas kontrol.

Dari hasil tes akhir (postes) yang di ikuti oleh siswa baik dari kelas eksperimen maupun kelas kontrol diperoleh rata-rata dan simpangan baku seperti pada tabel di bawah ini.

Tabel 6. Hasil Postes Tes Kemampuan Representasi Matematis

\begin{tabular}{|c|c|c|c|c|c|}
\hline Kelas & $\mathrm{N}$ & $X_{\text {maks }}$ & $X_{\min }$ & $\bar{X}$ & SD \\
\hline Eksperimen & 19 & 90 & 55 & 73,43 & 7,66 \\
\hline Kontrol & 18 & 90 & 45 & 66,67 & 9,41 \\
\hline
\end{tabular}

Untuk menguji kenormalan data skor hasil belajar digunakan uji lielifors diperoleh $\mathrm{L}$ tabel pada kelas eksperimen berada pada nilai kritis untuk $\alpha=0,05$ dan $\mathrm{n}=19$ adalah 0,195 dan $\mathrm{L}$ tabel kelas kontrol berada pada nilai kritis untuk $\alpha$ $=0,05$ dan $n=18$ adalah 0,200. Sehingga data pada kedua kelas berdistribusi normal pada taraf kepercayaan $95 \%$. Selanjutnya, hasil uji homogenitas varians kedua kelas diperoleh bahwa $\mathrm{F}$ hitung $<\mathrm{F}$ tabel $=1,59<2,24$, sehingga dapat disimpulkan bahwa varians kelompok eksperimen dan kontrol adalah homogen.

Karena data terdistribusi normal dan memiliki varians yang homogen, maka untuk uji kesamaan rerata kedua kelas digunakan uji-t. Hasil perhitungan uji-t diperoleh $\mathrm{t}$ hitung $>\mathrm{t}$ tabel $=2,35>$ 2,0315 maka $\mathrm{H}_{0}$ ditolak, artinya terdapat pengaruh model pembelajaran Student Facilitator and Explaining (SFE) dengan menggunakan media poster terhadap kemampuan representasi matematis siswa.

Pembelajaran dengan model Student Facilitator and Explaining memberikan kebebasan siswa baik untuk mengemukakan ide/gagasan mereka 
maupun menanggapi pendapat siswa lainnya, sehingga menuntut adanya komunikasi antarsiswa agar proses pembelajaran menjadi optimal. Selama proses pembelajaran, siswa diberikan lembar kerja yang dikerjakan secara kelompok. Pada diskusi pertama, siswa masih bingung mengerjakan lembar kerja tersebut karena siswa belum terbiasa mencari informasi sendiri yang terdapat dalam soal. Siswa yang pintar pun lebih senang mengerjakannya sendiri. Dari hal ini, terlihat interaksi antar siswa ketika belajar belum terjalin (Silberman, M., 2004).

Ketika siswa diminta menyampaikan ide dan menjelaskan hasil kerja, terdapat lebih dari sebagian siswa yang masih terlihat malu-malu dan sulit. Tidak sedikit siswa yang tidak menanggapi dan memberikan memberikan ide atas hasil presentasi temannya. Namun demikian, pada pertemuan selanjutnyasedikit demi sedikit siswa terbiasa dengan penggunaan model student facilitator and explaining dan terdapat perubahan positif dengan kemampuan komunikasi maematis siswa. Siswa tidak malu-malu lagi untuk menyampaikan ide/gagasan baik secara lisan maupun tulisan dengan simbul-simbul, grafik atau diagram untuk menjelaskan keadaan atau masalah dari informasi yang diperoleh baik ketika kerja kelompok maupun pengerjaan latihan soal. Dari hal itu terlihat terjalin interaksi lebih optimal, baik antarsiswa maupun dengan guru

Penerapan model pembelajaran yang tepat diharapkan dapat mengatasi rendahnya aktivitas belajar dan prestasi belajar siswa dengan cara menciptakan suasana yang menyebabkan terpacunya motivasi dan aktifitas belajar. Alternatif model pembelajaran yang diharapkan dapat mengaktifkan aktivitas dan prestasi belajar siswa adalah model pembalajaran kooperatif tipe Student Facilitator and Explaining (SFE). Dengan demikian aktivitas dan prestasi belajar siswa dapat ditingkatkan dengan model pembelajaran tipe Student Facilitator and Explaining (SFE), dengan menjadikan siswa sebagai fasilitator yang bertugas menjelaskan kepada siswa lainnya, dengan dibantu dengan bimbingan guru.

Student Facilitator and Explaining (SFE) dengan menggunakan media poster adalah sistem perseorangan yang cocok untuk segala usia. Dengan menempatkan pentingnya kemampuan setiap siswa, Student Facilitator and Explaining (SFE) dengan menggunakan media poster berkeinginan untuk membentuk dan menumbuhkan potensi sifat dan kemampuan belajar setiap individu. Model Student Facilitator and Explaining (SFE) dengan menggunakan media poster menggunakan bahan pelajaran berupa lembar kerja yang disusun sedemikian rupa secara sistematis dan small step yang berisi materi pelajaran matematika dari tingkat prasekolah sampai dengan tingkat SMA. Bahan pelajarannya dirancang sehingga siswa dapat mengerjakan dengan kemampuannya sendiri, bahkan memungkinkan bagi siswa untuk memperlajari bahan pelajaran di atas tingkatan kelasnya di sekolah. 
Proses pelaksanaan pembelajaran pada saat pertama kali diadakan dengan menggunakan model pembelajaran Student Facilitator and Explaining (SFE) dengan menggunakan media poster, kelas menjadi gaduh ketika siswa mengatur meja dan kursi untuk tiap masing-masing siswa. Sehingga sedikit mengganggu yang lain untuk belajar. Melihat hal tersebut guru memberikan pengertian kepada siswa untuk pertemuan selanjutnya sebelum kegiatan pembelajaran dimulai, semua anggota siswa harus berada dikursinya masing-masing, dan ketika menyusun kursi jangan menimbulkan kegaduhan, sehingga tidak mengganggu kelas yang lain.

Proses pembelajaran yang dilakukan pada awal penelitian tersebut sesuai dengan apa yang telah direncanakan, siswa memperhatikan dengan baik penjelasan guru namun aktifitas siswa masih tergolong kaku dan belum dapat aktif secara maksimal. Sebagaian besar siswa masih enggan bertanya juga ketika guru memberikan pertanyaan siswa hanya terlihat suara-suara kecil dan belum berani untuk diungkapkan kepada guru.

Pada pertemuan kedua siswa sudah mulai mengikuti proses pembelajaran ini dengan baik walaupun masih ada juga siswa yang ribut dan tidak memperhatikan serta mengikuti jalannya pembelajaran ini. Hal tersebut tidak berlangsung lama secara berangsur-angsur keadaan tersebut mulai membaik, mereka sudah mulai mengerti bagaimana proses pembelajaran aktif yang menggunakan model pembelajaran Student Facilitator and Explaining (SFE) dengan menggunakan media poster ini.

Pada pertemuan ketiga dan seterusnya siswa sudah mengikuti proses pembelajaran dengan baik, mulai berperan aktif terhadap penyelesaian masalah yang diberikan guru. Pada pertemuan ini siswa sudah bisa mengembangkan pengetahuannya sendiri, dimulai dari memahami masalah, merencanakan penyelesaian masalah, menyelesaikan masalah bahkan Melakukan pengecekan atas jawaban yang telah dikerjakan.

Pada penelitian ini, kemampuan komunikasi matematika siswa dilihat dari hasil pretest yang diberikan sebelum dilakukan pembelajaran dan postest yang diberikan pada akhir pertemuan. Tes yang diberikan berbentuk essay yang berjumlah 4 soal dimana setiap soal mempunyai bobot skor sesuai dengan indikator kemampuan komunikasi. Hasil pretest menunjukkan kondisi awal kemampuan komunikasi matematika siswa secara keseluruhan termasuk dalam kategori rendah. Namun setelah diberi perlakuan sebagaimana yang direncanakan, yaitu dibelajarkan dengan model pemebelajaran Student Facilitator and Explaining (SFE) dengan menggunakan media poster, barulah terlihat adanya perubahan pada kemampuan komunikasi matematika siswa.

Proses pembelajaran matematika siswa yang menggunakan model pemebelajaran Student Facilitator and Explaining (SFE) dengan menggunakan media poster dapat dilihat pada hasil tes akhir pada kelas eksperimen, dari tes 
tersebut diperoleh rata-rata 73,42. Hal ini menunjukkan bahwa proses belajar mengajar yang menggunakan model pembelajaran Student Facilitator and Explaining (SFE) dengan menggunakan media poste rdapat meningkatkan belajar matematika siswa yang sebelumnya masih di bawah KKM yang telah ditetapkan yaitu 65,00 .

Di kelas eksperimen menggunakan model pembelajaran Student Facilitator and Explaining (SFE) dengan menggunakan media poster pada pembelajaran ini guru mengintruksikan langkah-langkah model pembelajaran Student Facilitator and Explaining (SFE) dengan menggunakan media poster, kemudian guru meminta kepada seluruh siswa untuk melaksanakan proses pembelajaran sesuai dengan model pembelajaran Student Facilitator and Explaining (SFE) dengan menggunakan media poster di kelas eksperimen (kelas VII B SMP Negeri 7 Sungai Penuh Tahun Pelajaran 2019/2020). Adapun bentuk proses dan hasil beserta kendala peneliti proses penerapan model pembelajaran Student Facilitator and Explaining (SFE) dengan menggunakan media poster pada pembelajaran penyelesaian masalah matematika pada materi Statistika.

Berdasarkan hasil analisis data tes kemampuan representasi matematis, menunjukan bahwa terdapat pengaruh model pembelajaran Student Facilitator and Explaining (SFE) dengan menggunakan media poster terhadap kemampuan representasi matematis siswa pada kelas eksperimen. Hal ini menunjukan bahwa siswa cukup paham dengan materi yang disajikan dengan menggunakan model pembelajaran Student Facilitator and Explaining (SFE) dengan menggunakan media poster. Telah diketahui bahwa hasil nilai rata-rata siswa yang diajarkan menggunakan model pembelajaran Student Facilitator and Explaining (SFE) dengan menggunakan media poster adalah 73,42 ini berarti kemampuan representasi matematis siswa yang diperoleh siswa telah mencapai Kriteria Ketuntasan Minimal (KKM) yang telah ditentukan oleh guru bidang studi matematika. Hasil penelitian ini mendukung hasil Penelitian yang di lakukan oleh Silvia Rahma Yenti. Penerapan model pembelajaran Student Facilitator and Explaining dengan Make A Match untuk meningkatkan kemampuan komunikasi matematis Siswa Kelas VIII SMPN 3 Batipuh, hasil penelitian ini menunjukkan data kemampuan komunikasi matematis lisan siswa diperoleh melalui lembar observasi selama proses pembelajaran dengan model pembelajaran Student Facilitator and Explaining dengan Make A Match. Data yang diperoleh dianalisis dengan menggunakan rumus persentase. Sedangkan data kemampuan komunikasi matematis tulisan siswa diperoleh dari hasil pretest dan posttest menggunakan ngain. Berdasarkan hasil penelitian, kemampuan komunikasi matematis lisan siswa mengalami peningkatan setiap pertemuannya sehingga hipotesis penelitian diterima. Jadi, terdapat peningkatan kemampuan komunikasi matematis tulisan 
siswa melalui penerapan model pembelajaran Student Facilitator and Explaining dengan Make A Match (Yenti, S.R., 2018).

Dari pengalaman di kelas terlihat bahwa ternyata pembelajaran dengan menggunakan model pembelajaran Student Facilitator and Explaining (SFE) dengan menggunakan media poster memberi kesempatan kepada siswa untuk dapat terlibat secara aktif dalam kegiatan belajar. Hal ini dibuktikan melalui uji-t yang telah dibahas sebelumnya. Sehingga diperoleh terdapat pengaruh penerapan model pembelajaran Student Facilitator and Explaining (SFE) dengan menggunakan media poster terhadap kemampuan representasi matematis siswa di kelas VII SMP Negeri 7 Sungai Penuh Tahun Ajaran 2019/2020, pada tingkat kepercayaan $95 \%$.

\section{KESIMPULAN}

Berdasarkan uraian dan analisis bab-bab terdahulu maka dapt ditarik kesimpulan yaitu kemampuan representasi matematis siswa pada kelas kontrol yang tidak belajar dengan menggunakan model Student Facilitator and Explaining (SFE) dengan menggunakan media poster diperoleh nilai rata-rata sebesar 66,67 dengan standar deviasi 9,41. Sementara itu, kemampuan representasi matematis siswa pada kelas eksperimen yang belajar dengan menggunakan model Student Facilitator and Explaining (SFE) dengan menggunakan media poster diperoleh nilai rata-rata sebesar 73,42 dengan standar deviasi 7,66. Berdasarkan hasil tersebut dapat disimpulkan bahwa kemampuan representasi matematis siswa yang belajar dengan model Student Facilitator and Explaining (SFE) dengan menggunakan media poster lebih tinggi daripada siswa yang tidak belajar dengan model Student Facilitator and Explaining (SFE) dengan menggunakan media poster. Hal ini didukung dengan uji perbandingan rerata secara statistik dengan menggunakan uji-t, yaitu terdapat pengaruh model Student Facilitator and Explaining (SFE) dengan menggunakan media poster terhadap kemampuan representasi matematis siswa.

Dalam mengajar Matematika, guru atau calon guru dapat menggunakan meodel pembelajaran Student Facilitator and Explaining (SFE) dengan menggunakan media poster tidak hanya untuk pokok bahasan Statistika tapi juga untuk pokok bahasan lainnya. Diusahakan bagi guru untuk mengelola waktu dengan lebih efisien dalam menerapkan model pembelajaran Student Facilitator and Explaining (SFE) dengan menggunakan media poster dalam pembelajaran matematika. Perlu dilakukan penelitian lebih lanjut tentang pengembangan model pembelajaran Student Facilitator and Explaining (SFE) dengan menggunakan media lainnya dalam pembelajaran matematika, dan tidak tertutup kemungkinan jika dilakukan dalam ruang lingkup yang lebih luas pada sekolah dan tingkat pendidikan yang berbeda. 


\section{DAFTAR PUSTAKA}

Depertemen Pendidikan RI, Undang-Undang No 20 Tahun 2003 tentang Sistem Pendidikan Nasional.

Fauzi, M. N., \& Jati, N. H. D. (2016). Penerapan Model Pembelajaran Student Facilitator And Explaining (Sfe) Berbasis Mind Mapping Untuk Meningkatkan Kreativitas Siswa. In Prosiding Seminar Nasional Matematika dan Pendidikan Matematika.

Hasratuddin. (2013). Membangun Karakter melalui Pembelajaran Matematika. PARADIKMA: Jurnal Pendidikan Matematika, 6 (2), 130.

Huda, M., (2014). Model-Model Pengajaran Dan Pembelajaran, Yogyakarta: Pustaka Pelajar. Kaelan, MS (2010). Pendidikan Kewarganegaraan. Yogyakarta: Paradigma.

Maiyena, S. (2013). Pengembangan Media Poster Berbasis Pendidikan Karakteruntuk Materi Global Warming. Jurnal Materi dan Pembelajaran Fisika, 3(1).

Mulyasa, E. (2004). Implimentasi Kurikulum, Cetakan II. Bandung: Remaja Rosda Karya.

Nasution, E. Y. P. (2017). Meningkatkan Kemampuan Spasial Siswa Melalui Pembelajaran Geometri Berbantuan Cabri 3D. Mathline: Jurnal Matematika dan Pendidikan Matematika, 2(2), 179-194.

Rangkuti, A. N. (2013). Representasi matematis. Logaritma: Jurnal Ilmu-ilmu Pendidikan dan Sains, 1(02).

Saifuddin, A., Nasikh, N., \& Utomo, S. H. (2015). Penerapan Model Pembelajaran Student Facilitator And Explaining (SFE) dengan Menggunakan Peta Konsep Untuk Meningkatkan Keaktifan dan Prestasi Belajar Siswa pada Mata Pelajaran Ekonomi Kelas X Lintas Minat Ekonomi di SMA Negeri 02 Batu. Jurnal Pendidikan Ekonomi (Economic Education Journal), 8(1).

Sabirin, M. (2014). Representasi dalam pembelajaran matematika. Jurnal Pendidikan Matematika, 1(2), 33-44.

Silberman, M. (2004). Active Learning, 101 Strategi Pembelajaran Aktif (terjemahan Sarjuli et al.). Yogyakarta: Yappendis.

Yenti, S. R. (2018). Penerapan Model Pembelajaran Student Facilitator and Explaining dengan Make A Match untuk Meningkatkan Kemampuan Komunikasi Matematis Siswa Kelas VIII SMPN 3 Batipuh.

Zahara, R. (2017). Pengaruh Model Pembelajaran Student Facilitator and Explaining terhadap Hasil Belajar Konsep Cahaya pada Siswa Kelas VIII di SMP Negeri 9 Banda Aceh. Jurnal Prosding Seminar Nasional MIPA III. ISBN 978-602-50939-0-6. 